\title{
ANALISIS PELAKSANAAN AKAD MURABAHAH PADA PRODUK PEMBIAYAAN MODAL KERJA DI BMT UGT SIDOGIRI KEDIRI
}

\author{
Dian purnaningrum \\ Chamim Tohari \\ e-mail:purnanigrumdian@gmail.com
}

\begin{abstract}
ABSTRAK
Atas dasar peraturan yang berkaitan dengan murabahah baik yang bersumber dari fatwa DSN maupun PBI, perbankan syariah melaksanakan pembiayaan murabahah. Namun demikian, dalam praktiknya tidak ada keseragaman model penerapan pembiayaan murabahah karena beberapa faktor yang melatarbelakanginya. Pembiayaan merupakan salah satu pokok tugas bank, yaitu pemberian fasilitas penyediaan dana untuk memenuhi kebutuhan pihak pihak yang merupakan defisit unit.

Tujuan dalam penelitian ini adalah: (1) Untuk mendeskripsikan pelaksanaan akad murabahah pada produk pembiayaan modal kerja di BMT UGT Sidogiri Kediri. (2) Untuk mendeskripsikan analisis hukum Islam terhadap pelaksanaan akad murabahah pada produk pembiayaan modal kerja di BMT UGT Sidogiri Kediri.

Penelitian ini adalah penelitian kualitatif, yaitu berupa suatu prosedur penelitian yang menghasilkan data deskriptif berupa ucapan atau tulisan dan perilaku yang dapat diamati dari orang-orang (subjek) itu sendiri. Sumber data menjadi bahan pertimbaangan dalam penentuan metode pengumpulan data. Sumber data terdiri dari data primer dan data sekunder. Teknik analisa data yang digunakan tiga cara, yaitu: reduksi data, penyajian data, dan penarikan kesimpulan.

Kesimpulan hasil penelitian ini adalah: (1) Pembiayaan modal kerja di BMT UGT Sidogiri Kediri sangat abstrak, hal ini karena proses transaksi beralih antara nasabah dengan supplier atau pemasok, sehingga memungkinkan nasabah apakah akan benar-benar membelanjakan dana pembiayaan tersebut untuk membeli barang atau tidak. Berkaitan dengan harga, dalam pelaksanaan akad murabahah pada pembiayaan modal kerja pada BMT UGT Sidogiri Kediri untuk penentuan pembiayaan lebih tergantung pada besar kecilnya agunan yang disertakan oleh nasabah, padahal dalam murabahah, harga haruslah disesuaikan dengan pengeluaran untuk pembelian baran yang riil. (2) Penentuan persentase margin berdasarkan tingakat plafon pembiayaan yang dilakukan oleh BMT UGT Sidogiri Kediri menjadikan seperti bunga. Karena besar kecilnya keuntungan harus ditentukan bersama sesuai kesepakatan bersama pula. Selain itu, tidak diperbolehkan menyesuaikan lamanya jangka waktu pembiayaan karena dalam Islam melarang konsep time value of money, karena jika itu yang terjadi maka
\end{abstract}


akan sama halnya denga bunga. Penandatanganan akad dilakukan bersamaan (murabahah dan wakalah) oleh pihak bank dan nasabah menyebabkan ketidakjelasan akad, mekanisme pebelian dan kepemilikan barang yang diperjual belikan serta menjadikan akad tersebut rusak.

\section{Kata Kunci: Akad Murabahah, Pembiayaan Modal Kerja.}

\section{PENDAHULUAN}

Berdasarkan Undang-Undang konvensional membuka kantor cabang syari'ah yang merupakan tonggak penting dimulainya awal sistem perbankan di Indonesia, yaitu sebuah bank yang dapat beroperasi dengan dua sistem yang berbeda (dual banking system), namun dapat melengkapi pelayanan yang baik pada masyarakat. Penyempurnaan tentang Undang-Undang tersebut tidak berhenti di situ, dengan adanya Undang-Undang Nomor 21 Tahun 2008 yang mengatur secara terpisah tentang perbankan syari'ah telah memberikan angin segar bagi perbankan yang beroperasi dengan sistem syari'ah untuk terus melaju dalam dunia perbankan di Indonesia.

Di Indonesia, aplikasi jual beli murabahah pada perbankan syariah di dasarkan pada Keputusan Fatwa Dewan Syariah Nasional (DSN) Majelis Ulama Indonesia (MUI) dan Peraturan Bank Indonesia (PBI). Menurut keputusan fatwa DSN Nomor 04/DSN-MUI/IV/2000 ketentuan murabahah pada perbankan syariah adalah sebagai berikut:

a. Bank dan nasabah harus melakukan akad murabahah yang bebas riba.

b. Barang yang diperjualbelikan tidak diharamkan oleh syari'ah Islam.

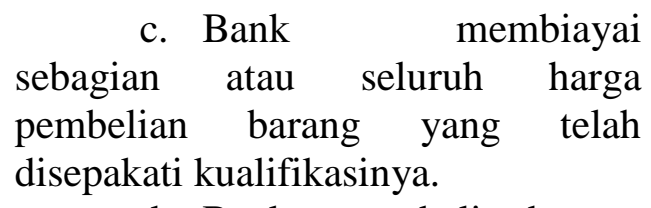

d. Bank membeli barang yang diperlukan nasabah atas nama bank sendiri, dan pembelian ini harus sah dan bebas riba.

e. Bank harus menyampaikan semua hal yang berkaitan dengan pembelian, misalnya jika pembelian dilakukan secara hutang.

f. Bank kemudian menjual barang tersebut kepada nasabah (pemesan) dengan harga jual senilai harga beli plus keuntungannya. Dalam kaitan ini Bank harus memberitahu secara jujur harga pokok barang kepada nasabah berikut biaya yang diperlukan.

g. Nasabah membayar harga barang yang telah disepakati tersebut pada jangka waktu tertentu yang telah disepakati.

h. Untuk mencegah terjadinya penyalahgunaan atau kerusakan akad tersebut, pihak bank dapat mengadakan perjanjian khusus dengan nasabah.

i. Jika bank hendak mewakilkan kepada nasabah untuk membeli barang dari pihak ketiga, akad jual beli murabahah harus dilakukan setelah barang, secara prinsip, menjadi milik bank. ${ }^{1}$

\footnotetext{
1 Dewan Syariah Nasional MUI dan Bank Indonesia, Himpunan Fatwa
} 
Bank syari'ah merupakan lembaga intermediasi dan penyedia jasa keuangan yang bekerja berdasarkan etika dan sistem Islam, khususnya yang bebas dari bunga (riba), bebas dari kegiatan spekulatif dan perjudian (maysir), bebas dari hal-hal yang tidak jelas (gharar), berprinsip keadilan, dan hanya membiayai kegiatan usaha yang halal yang kesemuanya merupakan prinsip-prinsip perbankan syari'ah. Bank syari'ah sering dipersamakan dengan bank tanpa bunga. Bank tanpa bunga merupakan konsep yang lebih sempit dari bank syari'ah, di mana sejumlah instrumen atau operasinya bebas dari bunga. Bank syari'ah selain menghindari bunga, juga secara aktif ikut berpartisipasi dalam mencapai sasaran dan tujuan dari ekonomi Islam yang berorientasi pada kesejahteraan sosial. ${ }^{2}$

Murabahah dalam fiqih Islam merupakan bentuk jual beli yang tidak ada hubungannya dengan pembiayaan pada mulanya. Murabahah dalam Islam berarti jual beli ketika penjual memberitahukan kepada pembeli biaya perolehan dan keuntungan yang diinginkannya. Namun demikian bentuk jual beli ini kemudian digunakan oleh perbankan syari'ah dengan menambah beberapa konsep lain sehingga menjadi bentuk pembiayaan. ${ }^{3}$

Dewan Syariah Nasional MUI, Gaung Persada, Jakarta, 2006, hal. 24-25

2 Muhammad Fauzi, Analisis Faktor-faktor yang Mempengaruhi Keinginan Migrasi Nasabah Bank Umum Syari'ah, IAIN Walisongo, Semarang, 2012, hal. 11.

3 Veithzal Rivai dan Andria Permata Veithzal, Islamic Financial Management: Teori, Konsep dan Aplikasi: Panduan Praktis Untuk Lembaga Keuangan,
Kajian penerapan prinsip syari'ah dalam operasi perbankan syari'ah merupakan agenda penting bagi perbankan nasional. Bank Indonesia telah mengkaji standarisasi akad produk perbankan syari'ah, diawali dari akad mudharabah, musyarakah dan murabahah, yang ditujukan untuk mengidentifikasi penerapan prinsip syari'ah dan kemungkinan variasinya dalam praktek, di sisi lain masyarakat telah memiliki persepsi bahwa bank syari'ah berbeda, lebih tinggi kualitas moralnya, etika dan bisnisnya dibandingkan dengan bank konvensional. ${ }^{4}$

Pembiayaan murabahah memiliki karaktersistik tersendiri. Pertama, akad yang digunakan dalam pembiayaan murabahah adalah akad jual beli. Kedua, barang dagangan harus tetap dalam tanggungan bank selama transaksi antara bank dan nasabah belum diselesaikan. Ketiga, keuntungan dalam pembiayaan murabahah berbentuk margin penjualan yang sudah termasuk harga jual. Keempat, pembayaran harga barang dilakukan secara tunai maupun cicil. Kelima, pembiayaan murabahah memungkinkan adanya jaminan. ${ }^{5}$

Dalam pelayanan produk pembiayaan baik untuk keperluan konsumtif, investasi, maupun produktif hanya menggunakan akad murabahah.Sehingga, keperluan

Nasabah, Praktisi, dan Mahasiswa, Raja Grafindo Persada, Jakarta, 2013, hal. 17.

4 Muhammad Fauzi, Implementasi Prinsip Syari'ah pada Perbankan Syari'ah, IAIN Walisongo, Semarang, 2016, hal. 4.

5 Andria, Manajemen Bank Syari'ah, Raja Grafindo Persada, Jakarta, 2014, hal. 780 . 
pembiayaan pada mitra usaha yang sifatnya produktif juga menggunakan akad murabahah. Karena umumnya pembiayaanmitra usahayang sifatnya produktifitu cenderung menggunakan akad mudharabah musyarakah. Tapi dalam prakteknya, akad murabahah itu diterapkan pada produk pembiayaan modal kerja di BMT UGT Sidogiri Kediri.

Dalam pelayanan produk pembiayaan yang ditawarkan di BMT UGT Sidogiri Kediri hanya menggunakan akad murabahah, baik itu pembiayaan untuk keperluan konsumtif, investasi maupun produktif. Sehingga keperluan pembiayaan untuk kebutuhan modal usaha yang sifatnya produktif pun menggunakan akad murabahah. Dengan adanya fenomena semacam itu tentunya menjadi suatu hal yang menarik, karena pada umumnya pembiayaan modal usaha yang sifatnya produktif cenderung menggunakan akad mudharabah atau musyarakah. Dalam prakteknya, akad murabahah yang diterapkan untuk produk Pembiayaan Modal Kerja di BMT UGT Sidogiri Kediri terkesan perlakuanya seperti akad mudharabah.

\section{PEMBAHASAN}

\section{Pelaksanaan Pembiayaan Murabahah}

Produk pembiayaan modal kerja dengan akad murabahah pada BMT UGT Sidogiri Kediri biasa disebut dengan Pembiayaan Modal Kerja, pembiayaan ini adalah pembiayaan usaha produktif sesuai syari'ah. Produk pembiayaan modal kerja ini disediakan oleh BMT UGT Sidogiri Kediri adalah pada kantor unit yang memberikan layananan khusus untuk pembiayaan usaha skala mikro. ${ }^{6}$

Pembiayaan murabahah pada produk modal kerja mencapai $100 \%$ dari total pembiayaan yang ada di BMT UGT Sidogiri Kediri. Hal ini terjadi karena layanan BMT UGT Sidogiri Kediri merupakan kantor unit dari BMT UGT Sidogiri Kediri yang khusus melayani pembiayaan sekala mikro dengan akad murabahah. ${ }^{7}$

\section{Mekanisme Pembiayaan}

Mekanisme dalam pembiayaan modal kerja dengan skim murabahah pada BMT UGT Sidogiri Kediri adalah sebagai berikut: ${ }^{8}$

1) Pengajuan

Permohonan dan Negosiasi

Dalam proses pembiayaan murabahah pada BMT UGT Sidogiri Kediri langkah awal yang ditempuh adalah proses pengajuan permohonan.

2) Proses Akad

Setelah proses pengajuran dan negosiasi selesai dan pihak bank mengabulkan permohonan pengajuan pembiayaan yang diajukan oleh nasabah, maka selanjutnya adalah proses akad anatara kedua belah pihak.

3) Pencairan

Pembiayaan

Setelah terjadi kesepakatan anatara kedua belah pihak (bank dan

6 Wawancara dengan Bapak A. Saifulloh Naji, Wakil Ketua II BMT UGT Sidogiri Kediri, di kantor, 13 Januari 2018.

7 Wawancara dengan Bapak Ahmad Erfan Afandi, Direktur Keuangan BMT UGT Sidogiri Kediri, di kantor, 15 Januari 2018.

8 Wawancara dengan Bapak A. Saifulloh Muhyidin, Bendahara BMT UGT Sidogiri Kediri, di kantor, 17 Januari 2018. 
nasabah) dengan ditandatanganinya akad murabahah dan wakalah, maka pihak nasabah yang mengajukan pembiayaan bisa melakukan pencairan dana pinjamam dari BMT UGT Sidogiri Kediri.

4) Proses Pembelian

Barang

Dalam proses pembelian barang, sesuai yang telah dijelaskan pada bagian akad di atas bahwa untuk pembelian barang dilakukan oleh pihak nasabah karena adanya akad wakalah (bank mewakilkan nasabah untuk pembelian barang).

5) Pembayaran

Angsuran

Setelah nasabah menerima dana pembiayaan dari pihak bank dan telah melakukan pembelian atas suatu barang untuk keperluan modal kerja, maka nasabah mempunyai kewajiban untuk membayar pinjaman modal dan margin (harga beli) kepada BMT UGT Sidogiri Kediri secara mengangsur selama jangka waktu yang telah ditentukan di awal akad. Sedangkan waktu pembayaran angsuran dilakukan pada hari kerja bank. ${ }^{9}$

\section{Analisis Hasil Penelitian}

\section{a. Analisis Rukun Murabahah} pada Pembiayaan Modal Kerja

Perbankan konvensional sebagi pemain lama telah menawarkan berbagai produk kredit untuk memenuhi kebutuhan para nasabahnya, sedangkan bank syariah dalam hal tersebut juga memiliki produk untuk dapat mengakomodasi keinginan dari para nasabahnya yaitu berupa produk pembiayaan salah

9 Wawancara dengan
Bhmad Erfan Afandi, Direktur Keuangan
BMT UGT Sidogiri Kediri, di kantor, 15
Januari 2018.

satunya adalah pembiayaan dengan akad murabahah.

Dalam perbankan syari'ah, ada dua bentuk murabahah yang umumnya dipraktekkan, yakni:

1) Murabahah modal kerja adalah akad jual beli antara bank selaku penyedia barang dengan nasabah selaku pemesan untuk membeli barang. Dari transaksi tersebut bank mendapatkan keuntungan jual beli yang disepakati bersama. Atau menjual suatu barang dengan harga asal (modal) ditambah dengan margin keuntungan yang disepakati.

2) Murabahah investasi, yaitu suatu perjanjian jual beli untuk barang tertentu antara pemilik dan pembeli, dimana pemilik barang akan menyerahkan barang seketika sedangkan pembayaran dilakukan dengan cicilan dalam jangka waktu yang disepakati bersama.

Dalam produk murabahah pada BMT UGT Sidogiri Kediri yang digunakan adalah murabahah modal kerja dengan system pembayaran cicilan dimana produk tersebut untuk mengakomodir kebutuhan pembiayaan bagi para nasabah untuk modal kerja.

Pelaksanaan akad murabahah pada pembiayaan modal kerja di BMT UGT Sidogiri Kediri apakah sesuai dengan ketentuan syari'ah atau tidak dapat dilihat dari analisis kesesuain praktek dengan kaidahkaidah fiqih tentang murabahah. Dalam fiqh sebagaimana sudah dijelaskan bahwa rukun dari murabahah adalah sebagai berikut: ${ }^{10}$

1) Para pihak (al-'aqidaen, العاقدين);

${ }^{10}$ A. Mas'adi Hufron, Fiqh Muamalah Kontekstual, PT. Raja Grafindo Persada, Jakarta, 2012, hal. 13. 
2) Pernyataan kehendak (sigat al-'aqd, (صيغة العقد);

3) Obyek akad (mahall al-'aqd, محل العقد (الع);

4) Tujuan akad (maudu al-'aqd, موضوع (العقد

Adapun rukun murabahah dalam praktek perbakan syari'ah sebgaimana yang disampaikan oleh Muhammad Syafi'i Antonio dan Arison Hendri, adalah sebagai berikut: ${ }^{11}$

1) Adanya penjual (ba'i) dan pembeli (musytari)

2) Adanya objek atau barang (mabi') yang diperjualbelikan

3) Adanya kesepakatan harga (tsaman)

4) Adanya ijab qabul (sighat)

5) Tujuan Akad

Sehingga dapat di pahami bahwa murabahah dalam praktek perbankan sama dengan rukun yang ditentukan dalam fiqih muamalah. Sedangkan rukun akad murabahah dalam pelaksanaan pembiayaan murabahah pada layanan BMT UGT Sidogiri Kediri dapat dijelaskan sebagai berikut:

1) Para pihak (العاقدين) adalah sebagai berikut: Sebagai penjual (ba'i), yaitu pihak BMT UGT Sidogiri Kediri dan sebagai pembeli (musytari) adalah pihak nasabah yang mengajukan pembiayaan modal kerja, itu adalah merupakan struktur pada akad murabahah. Sedangkan struktur pada akad wakalah yang menjadi penjual adalah produsen/supplier sedangkan pembelinya adalah nasabah. Karena dalam produk pembiayaan modal kerja pada BMT UGT Sidogiri Kediri terdiri dari dua akad yaitu murabahah dan wakalah.

\footnotetext{
${ }^{11}$ Arison Hendry, Perbankan Syari'ah: Perspektif Praktisi, Mu'amalat Institute, Jakarta, 2011, hal. 43.
}

2) Objek atau barang (محل العقد) yang diperjual belikan adalah kebutuhan barang atau peralatan yang dibutuhkan nasabah dalam pengajuan berupa alat-alat untuk modal kerja yang halal.

3) Kesepakatan harga (tsaman) berupa adanya kesepakatan harga jual dan harga beli

4) Ijab qabul (صيغة العقد) ditunjukan dengan adanya pengisian dan penandatanganan formulir aplikasi akad murabhah dan akad tambahan wakalah antara nasabah dengan pihak BMT UGT Sidogiri Kediri.

5) Tujuan Akadnya (موضوع العقد) adalah untuk modal kerja nasabah yang mengajukan pembiayaan.

Dari uraian di atas dapat dilihat bahwa ketentuan rukun murabahah dalam fiqh muamalah maupun aplikasinya dalam perbankan syari'ah telah terpenuhi. Hal ini bisa dilihat dari pelaksanaan murabahah pada BMT UGT Sidogiri Kediri, baik itu pihak yang berakad, objek akad, harga, ijab qabul dan tujuan dari akad tersebut telah ada. Sehingga dapat disimpulkan bahwa rukun akad murabahah pada pembiayaan modal kerja BMT UGT Sidogiri Kediri telah terpenuhi dan telah sesuai dengan ketentuan syari'ah. 


\section{b. Analisis Syarat Murabahah pada Pembiayaan Modal Kerja}

Analisis dari syarat rukun dari pelaksanaan akad murabahah pada pembiayaan modal kerja di BMT UGT Sidogiri Kediri ini adalah sebagai berikut:

1) Nasabah dan Bank (Pihak yang berakad)

Dalam fiqh telah dijelaskan bahwa syarat yang harus dipenuhi oleh orang yang berakat (العاقدين) yaitu penjual dan pembeli adalah harus tamyis yaitu sesorang tersebut sudah mengetahui mana yang baik dan yang buruk serta dapat dikenai hukum. Dalam hal ini, kedua belah pihak yaitu bank dan nasabah yang mengajukan pembiayaan modal kerja haruslah tamyis. ${ }^{12}$ Sebagai pihak penjual yaitu BMT UGT Sidogiri Kediri, ini adalah berbentuk lembaga maka ketentuan yang berlaku haruslah lembaga tersebut adalah lembaga yang sah dan memiliki kemampuan untuk melakukan transaksi. Dalam hal ini BMT UGT Sidogiri Kediri adalah lembaga yang sah dan memiliki kemampuan untuk melakukan transaksi, maka BMT UGT Sidogiri Kediri tersebut sah sebagai penjual dalam transaksi murabahah pada pembiayaan modal kerja.

yaitu $\begin{gathered}\text { Sedangkan pihak pembeli } \\ \text { nasabah }\end{gathered}$ sebagaimana yang disyaratkan di atas yaitu tamzis, maka nasabah yang bisa mengajukan pembiayaan modal kerja hanyalah nasabah yang sudah bisa dijatuhi hukuman. Dalam pelaksanaan pada pembiayaan modal kerja di BMT UGT Sidogiri Kediri

13. telah disyaratkan bahwa nasabah haruslah sudah memiliki KTP (Kartu Tanda Penduduk) yang berarti harus sudah berusia minimal 17 tahun atau sudah menikah. Sehingga dari persyaratan tersebut sudah membuktikan bahwa nasabah sudah memenuhi persyaratan baik secara hukum positif maupun secara fiqh. 
2) Pembelian barang modal kerja (Objek akad)

Dalam ketentuan syarat dari objek (محل العقد) dalam akad murabahah sebagaimana yang telah dijelaskan dalam fiqh maupun konsep murabahah dalam perbankan yang dijabarkan dalam fatwa Dewan Syariah Nasional Nomor 04/ DSNMUI/IV/2000.

3) Harga jual dan harga beli (Kesepakatan harga)

Dalam pelaksanaan akad murabahah pada pembiayaan modal kerja pada BMT UGT Sidogiri Kediri untuk penentuan harga serta keuntungan lebih tergantung pada besar kecilnya agunan yang disertakan oleh nasabah. Mekanisme akad murabahah pada produk pembiayaan modal kerja BMT UGT Sidogiri Kediri, tahap awal yang dilakukan adalah pengajuan permohonan dan negosiasia antara pihak nasabah dengan pihak BMT UGT Sidogiri Kediri.

Syarat berkaitan harga perlu diperhatikan oleh pihak BMT UGT Sidogiri Kediri agar lebih sesuai dengan ketentuan sebagaimana yang konsep murabahah dalam fiqih maupun dalam teori perbankan syari'ah yang telah diatur dalam Fatwa Dewan Syariah Nasional Nomor 04/ DSN-MUI/IV/2000.

4) Penandatanganan Perjanjian Murabahah (Ijab Qabul)

Sebagaimana yang telah diurakan di atas, dalam pelaksanaan murabahah pada modal kerja di BMT UGT Sidogiri Kediri menggunakan akan tambahan wakalah dan qord (untuk fasilitas take over). Dengan adanya akad tambahan wakalah, menjadikan skim ini berbeda dari skim murabahah dalam konsep figh.
Secara akad, keseluruhan akad baik murabahah, wakalah dan qard (bagi fasilitas take over) dilakukan dalam satu kesatuan. Sedangkan pernyataan kehendak/ijab qabul (صيغة العقد) telah dituangkan secara tertulis dalam penandatangan perjanjian form aplikasi akad murabahah, begitu juga dengan akad wakalah dan qard. Dengan demikian syarat rukun dari sighat/ijab qabul telah sesuai dengan konsep syari'ah.

Tujuan dari adanya akad murabahah adalah untuk memenuhi kebutuhan nasabah dalam hal ini adalah untuk pemenuhan kebutuhan modal kerja. Akan tetapi jika kita melihat praktek murabahah dalam produk pembiayaan modal kerja di BMT UGT Sidogiri Kediri, penilaian besar-kecilnya plafon yang diberikan kepada nasabah bergantung kepada besar-kecilnya jaminan, maka akan menimbulkan diskriminasi terhadap nasabah yang kurang atau tidak memiliki cukup jaminan. Semestinya yang menjadi tolak ukur dari besarkecilnya pembiayaan adalah kebutuhan permodalan seorang nasabah, semagaimana yang telah dijelaskan dalam konsep murabahah pada perbankan syari'ah. Hal tersebut juga akan memberikan dampak yang lebih adil bagi seluruh nasabah.

\section{PENUTUP}

\section{Kesimpulan}

a. Pembiayaan modal kerja di BMT UGT Sidogiri Kediri sangat abstrak, hal ini karena proses transaksi beralih antara nasabah dengan supplier atau pemasok, sehingga memungkinkan nasabah apakah akan benar-benar membelanjakan dana pembiayaan tersebut untuk membeli barang 
atau tidak. Berkaitan dengan harga, dalam pelaksanaan akad murabahah pada pembiayaan modal kerja pada BMT UGT Sidogiri Kediri untuk penentuan pembiayaan lebih tergantung pada besar kecilnya agunan yang disertakan oleh nasabah, padahal dalam murabahah, harga haruslah disesuaikan dengan pengeluaran untuk pembelian baran yang riil.

b. Penentuan persentase margin berdasarkan tingakat plafon pembiayaan yang dilakukan oleh BMT UGT Sidogiri Kediri menjadikan seperti bunga. Karena besar kecilnya keuntungan harus ditentukan bersama sesuai kesepakatan bersama pula. Selain itu, tidak diperbolehkan menyesuaikan lamanya jangka waktu pembiayaan karena dalam Islam melarang konsep time value of money, karena jika itu yang terjadi maka akan sama halnya denga bunga. Penandatanganan akad dilakukan bersamaan (murabahah dan wakalah) oleh pihak bank dan nasabah menyebabkan ketidakjelasan akad, mekanisme pebelian dan kepemilikan barang yang diperjual belikan serta menjadikan akad tersebut rusak.

\section{Saran}

a. Dalam perbankan syari'ah, tidak cukup memiliki label "syari'ah" saja, melainkan harus benar-benar melaksanakan kegiatan baik itu yang bersifat penghimpunan (funding), pembiayaan (landing) maupun jasa (service) yang sesuai dengan ketentuan syari'ah dengan prinsip kehati-hatian agar terwujud suasana bermuamalah yang bebas riba. b. Jika BMT UGT Sidogiri Kediri hendak mewakilkan kepada nasabah untuk membeli barang dari pihak ketiga, maka akad murabahah dilakukan setelah kepemilikan barang secara prinsip dikuasai oleh BMT UGT. Pemberian kuasa (wakalah) dari BMT UGT Sidogiri Kediri kepada nasabah atau pihak ketiga manapun, harus dilakukan sebelum akad murabahah terjadi, penyimpangan wakalah ini terjadi karena akad wakalah dilaksanakan bersamaan atau mendahului akad murabahah tersebut.

c. Penentuan besar-kecilnya pembiayaan pada produk murabahah hendaknya ditentukan berdasarkan besar-kecilnya pembiayaan atas barang modal kerja yang riil, bukan berdasarkan pada besar-kecilnya nilai jaminan yang disertakan, karena jaminan hanya sebatas pengikat dalam perjanjian.

d. Perlua adanya ketegasan terutama oleh pihak BMT UGT Sidogiri Kediri dalam pelaksanaan akad murabahah pada pembiayaan modal kerja ini, terutama dalam pelaksanaan perjanjian yang telah disepakati bersama sebagaimana dalam aplikasi perjanjian dan Fatwa DSN.

e. Mudharabah merupakan akad kerjasama antara shahibul maal (nasabah) dan mudharib (bank), sehingga dalam hal ini perlu adanya transparansi antar keduanya, khususnya mengenai mekanisme perhitungan bagi hasil nasabah, sehingga akan tercipta kepercayaan antar kedua belah pihak, khususnya nasabah dalam menginvestasikan dananya. 


\section{DAFTAR PUSTAKA}

Andria, Manajemen Bank Syari'ah, Raja Grafindo Persada, Jakarta, 2014.

Dewan Syariah Nasional MUI dan Bank Indonesia, Himpunan Fatwa Dewan Syariah Nasional MUI, Gaung Persada, Jakarta, 2016.

Fauzi, Muhammad, Analisis Faktorfaktor yang Mempengaruhi Keinginan Migrasi Nasabah Bank Umum Syari'ah, IAIN Walisongo, Semarang, 2012.

Gunawan, Imam, Metode Penelitian Kualitatif Teori dan Praktik, Bumi Aksara, Jakarta, 2013.

Hendry, Arison, Perbankan Syari'ah: Perspektif Praktisi, Mu'amalat Institute, Jakarta, 2011.

Hufron, A. Mas'adi, Fiqh Muamalah Kontekstual, PT. Raja Grafindo Persada, Jakarta, 2012.

Miles, Mathew B. dan A. Michael Huberman, Analisis Data Kulaitatif, UI Press, Jakarta, 2012.

Moleong, Lexy J., Metodologi Penelitian Kualitatif, Ramaja Rosdakarya, Bandung, 2014.

Purhantara, Wahyu, Metode Penelitian Kualitatif untuk Bisnis, Graha Ilmu, Yogyakarta, 2014. Implementasi Prinsip Syari'ah pada Perbankan Syari'ah, IAIN Walisongo, Semarang, 2016.

Rivai, Veithzal dan Andria Permata Veithzal, Islamic Financial Management: Teori, Konsep dan Aplikasi: Panduan Praktis Untuk Lembaga
Keuangan, Nasabah, Praktisi, dan Mahasiswa, Raja Grafindo Persada, Jakarta, 2013. 